\title{
Modeling and Economic Analysis of Energy Generation from Biomass Energy
}

\author{
Gurinder Pal Singh Brar \\ Research Scholar \\ SLIET, Longowal \\ Punjab
}

\author{
V K Jain, Ph.D. \\ Professor \\ SLIET, Longowal \\ Punjab
}

\author{
Amanpreet Singh, Ph.D. \\ Associate Professor \\ SLIET, Longowal \\ Punjab
}

\begin{abstract}
Renewable energy has an imperative role in this world nowadays. The Renewable energy is derived from natural resources like sun light, rain, wind, tides and geothermal heat which are physically replenishing day by day. Wind energy, solar energy, bio-fuel, biomass and geothermal energy are the main types of renewable energies used at the moment. Out of these types, Bio-mass has a pertinent role in the generation of electric power as it is available all the time. Village households basically rely on wood and cow dung and other crop residues to meet up their energy necessities. Conversely, solar home system (SHS) is getting fashionable in the nongrid areas, but per unit cost of this electricity is extremely elevated. Poor households cannot afford to buy such a luxurious system. Bio-degradable waste which has not been used efficiently in the past can be used as a source for Electric Power Generation (EPG). Heating of bio-degradable waste produces methane gas which can be used to produce electricity using methanol fuel cells. This paper presents methodology of power generation using methanol fuel cells and the environmental and socio-economic aspects of biogas plant in a small community or village. At the end, an effective representation to develop and run a bio gas plant has been recommended.
\end{abstract}

\section{Keywords}

Renewable energy, solar energy, Bio-degradable waste, Biogas.

\section{INTRODUCTION}

Source of renewable energy are natural sources such as wind, sunlight, tides or plants that are almost inexhaustible. These sources are regenerated rather quickly compared to fossil sources of energy. India is one of the most attractive countries for renewable energy investments. Currently, the Ministry of New and Renewable Energy (MNRE) promotes the use of all sources of renewable energy. A growing share of renewable energy sources provides environmental advantages beside economic and social benefits. Renewable energies can help the country to meet the energy demand with domestic resources and can prevent the nation from large energy import bills which would influence the current account. Moreover potential use of these sources can build up protection against fuel price volatility and reduce the countries dependence on import and vulnerability to increasing energy prices.

Additionally, the country's development can be enhanced by the utilization of unused unemployed land as solar or wind parks and by supporting rural areas in their progress regarding energy supply. A reduction of social disadvantages due to the inaccessibility of the energy grid and convenient energy resources can be achieved through decentralized energy generation. According to the World Bank (2010b) report, one gigawatt of energy generated from renewable energy sources instead of fossil energy sources can reduce carbon emissions by 3.3 million tons a year. India is currently the world's fifth largest producer of energy from wind after Denmark Germany, Spain and the United States. Other renewable energy resources such as hydro, solar and biomass energy are used to supply the domestic market with energy (India Energy Portal, 2012). As mentioned earlier, the domestic supply has to grow up at a high rapidity to surmount the demand-supply breach.

Bio-gas is a non-toxic, monochrome, odorless, incombustible gas which is produced by the putrefaction of organic substances and biomass decomposition (fermentation). Biogas can be formed from diverse types of organic materials including animal, human, industrial, plant (crop) wastes and energy crops etc. Unlike natural gas, it is possible to receive in industrial conditions by fermentation an organic waste and specially grown up power plants. Biomass is one of the major energy sources used in rural India covering nearly $96 \%$ of energy sources; however its utilization is highly inefficient due to a lack of proper stoves in most households (Reddy and Ravindranath, 1987). Through the installation of a biogas plant and by providing more efficient stoves and biogas lamps to low and middle income receivers in rural India, a community can be provided with a more efficient alternative source of energy due to its wide availability in villages involved in cattle breeding and agricultural production.

\section{AVERAGE DECOMPOSITION OF DIGESTER BIOGAS}

Being close to natural gas under characteristics, bio-gas can be used in the same purposes like as manufacture of the electric power, heat, automobile fuel etc. and at due measure of clearing becomes indistinguishable to it on structure. Thus, we can say that bio-gas is renewed analogue of natural gas. Manufacture of bio-gas not only does not consume the electric power, it gives unrefined materials for its development and relieves the enterprises of prerequisite to put down a gas pipeline and to install electrical equipment from public networks.

Table 1: Composition of biogas

\begin{tabular}{|c|c|}
\hline Matter & Content \% \\
\hline Methane, $\mathrm{CH}_{4}$ & $50-70$ \\
\hline Carbon dioxide, $\mathrm{CO}_{2}$ & $50-30$ \\
\hline Nitrogen, $\mathrm{N}_{2}$ & $1-5$ \\
\hline Hydrogen, $\mathrm{H}_{2}$ & $0-3$ \\
\hline Hydrogen sulphide, $\mathrm{H}_{2} \mathrm{~S}$ & $0.1-0.5$ \\
\hline Oxygen, $\mathrm{O}_{2}$ & traces \\
\hline
\end{tabular}




\section{PROPERTIES OF BIOGAS}

Some properties of bio-gas are shown below;

1. Bio-gas is about $20 \%$ lighter than air.

2. Bio-gas has an approximate specific gravity of 0.86 and flame speed factor of 11.1

3. Bio-gas has an ignition temperature range of $650 \mathrm{o}$ to 750 o C.

4. Bio-gas is a colorless and odorless gas that burns with clear blue flame similar to that of Liquefied Petroleum Gas (LPG).

5. Bio-gas firing efficiency is 1.94 times more than fresh cow-dung cake.

6. Each $1 \mathrm{~m} 3$ of bio-gas is equal in calorific value to about $0.62 \mathrm{~m} 3$ of methane, $0.55 \mathrm{~m} 3$ of natural gas, 0.7 liter of gasoline (petrol) and $0.62 \mathrm{~m} 3$ liter of diesel.

7. A $1 \mathrm{~m} 3$ bio-gas will generate $4500-5500 \mathrm{Kcal} / \mathrm{m} 3$ (500-700 BTU/ft3) and when burned in efficient burners can produce $5.0 \mathrm{Kwh} / \mathrm{m} 3$.

345.6 liters per day of waste material which includes kitchen waste, toilet and washroom waste per day. Each cattle disposes of 8-10 kg +20 liters fresh manure per day. $1 \mathrm{~kg}$ of fresh cattle manures process $0.036 \mathrm{~cm} 3$ of biogas.

\section{ENERGY FROM BIOMASS}

Biomass includes the recyclable portion of products, wastes and residues of organic origin from agriculture (as plants and animals and their by-products), forestry and related industries as well as the biodegradable fraction from industrial and municipal waste. Currently, biomass in India is not used sustainably. In order to produce energy through the use of firewood, the pace of cutting down trees and bushed outpaces their ability to regenerate (Eltrop, 2005). A sustainable generation of energy from biomass in rural India requires the transformation of inefficient or unused biomass from animal waste and plant waste into an efficient energy source. Since India is situated in a biogas conductive temperature zone, biogas energy generation from biomass will be more efficient use of biomass waste. This biomass waste can accrue from agricultural, industrial or communal area (Flaig, 1998). Regarding different origins, biomass can be agricultural waste and liquid or solid manure; organic industrial waste water and industrial waste itself from plant or animal background and communal waste like sewage sludge. The production of biomass in rural areas is dependent on the agricultural situation and the amount of given livestock, the local industry (for example breweries, creameries, slaughterhouses or sugar refineries) and the communal circumstances. For operating a plant that produces biogas from biomass, the future development of the above mentioned areas is important for ensuring a sustainable operation. However, India has the largest population of cattle and buffaloes in the world and the future development might stay stable due to religious reasons. Therefore, the major part of the rural biomass potential can be based on bovine manure.

\section{ENERGY FROM A BIOGAS PLANT}

Biogas is a product of an anaerobic biological process called methanogenesis, which takes place without the impact of oxygen and a technical process called bio-methanation. The gas is a mixture of methane $(\mathrm{CH} 4)$ and carbon dioxide $(\mathrm{CO} 2)$ as well as parts of oxygen, nitrogen and some other trace gases. Usually, biogas contains 50 to $80 \%$ of $\mathrm{CH} 4$ and has between 15 and $45 \% \mathrm{CO} 2$, whereas the carbon dioxide share has a significant influence on the energy value of the gas (Table 2). The purer the biogas the less $\mathrm{CO} 2$ is included and the more energy the gas contains. Moreover, the increase in energy is exponential. Therefore, high methane shares are embattled for efficient biogas manufacture.

Table 2: Biogas composition and energy value, Substrates and gas yields

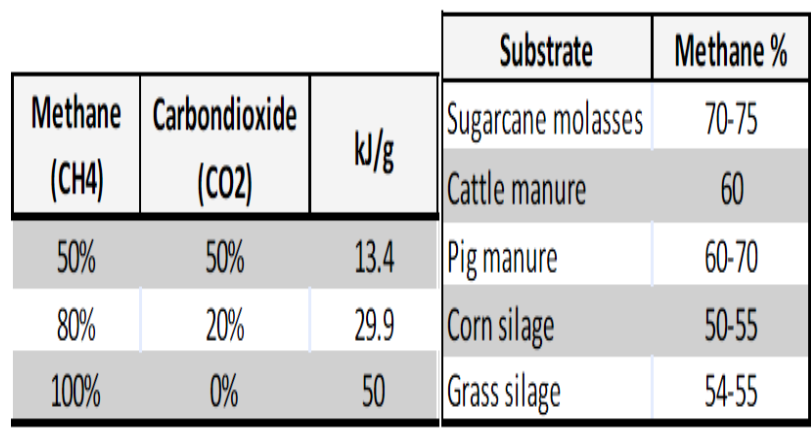

Some of the high methane shares substrates can be seen in Table 2. Different types of substrate have different gas yields. Sugarcane molasses (agro-waste) and cattle manure have high methane proportions and therefore are highly eligible as input factors for a biomass plant. Benefits of the biogas plant include the generated as well as highly efficient natural fertilizer given as a side product of the energy generating process (see Figure 2).The type of biogas plant, which is installed the most in rural areas and which will be installed by the project company is the fixed dome plant type (NABARD, 2012). The fixed dome biogas plant has usually three components: the inlet collection tank, a fermentor and the outlet storage tank.

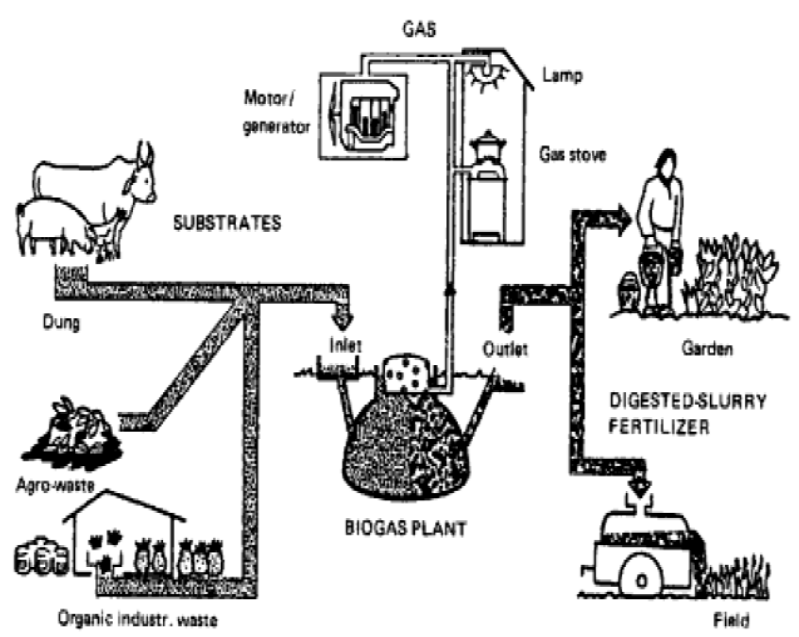

Figure 1: A typical biogas system configuration

The heart of the plant is the fermentor, often termed as the biogas plant itself. It is a vessel in which the biomass is metabolized and the biogas is produced. Methane escapes spontaneously from fermentation and no particular process is necessary for the recovery of methane. The vessel has to be air- and waterproof as well as corrosion resistant and thermally isolated in order to ensure a proper anaerobic biological process. The collection tank is installed in front of the fermentor and it is a container in which the input biomass is collected. 


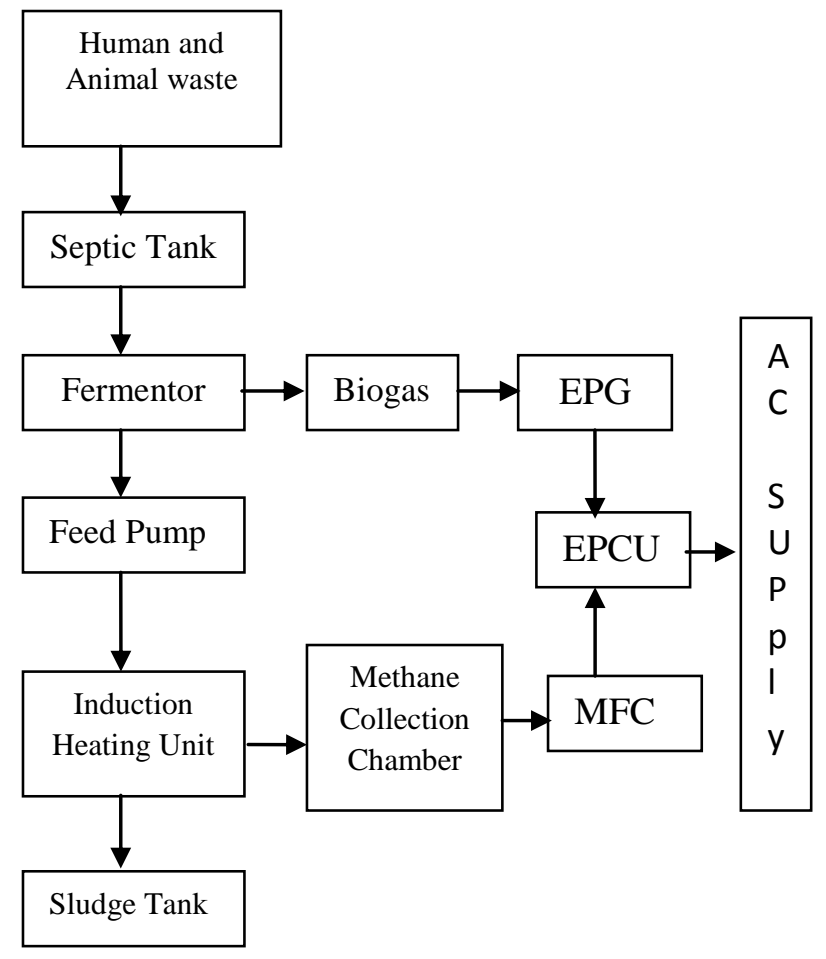

Figure 2: Biogas electric power generation plant

Through a flow system, a constant stream of biomass from the collection tank to the fermentor is possible although there is only irregular replenishment. Under optimal conditions of an anaerobic digestion, the slurry warms itself up to the required temperature between $28^{\circ}$ and $37^{\circ} \mathrm{C}$, which makes additional heating obsolete. Depending on the volume of the digester, the slurry is fully rotten in the vessel within 18 to 35 days. Thereafter, the fermented mixture will be displaced in the third container - the storage tank. It serves as storage place until the mixture is used as a fertilizer for fields. [13]

\section{PLANT LAYOUT AND DESCRIPTION}

The figure 2 presented the block diagram of the Biogas electric power generation plant.

\subsection{Waste Collection and Fermentation}

The human waste and animal dung is taken from a house of four family members and two cows. The waste is collected in the septic tank and is passed to fermnetor tank which is sealed air tight. The decomposition process of solid waste takes one month and that liquid waste is completed in about one week. The digestion occurred in four steps Hydrolysis, acidogensis, acitogensis and methanogensis. The reaction takes place at low temperature as a result small amount of methane gas is produced which is used for heating and small electric power generation (EPG).

\subsection{Heating Unit}

From the fermentor the waste in the semi solid form is passed to heating unit with the help of feed pump. The heating of waste is done with induction heater of capacity $7.5 \mathrm{KW}$ in the work. The copper coil is wound around the steel pipe through which the waste is passed. The Heater is supplied from electric power control unit (EPCU). The temperature is maintened at 35 degree cent. The methane gas is produced along with wet water vapors and the sludge is passed to sludge collection tank and is ready to use for fertilization purpose.

\subsection{Methane Collection Chamber}

The methane gas and water vapors from the heater pipe are passed to a chamber called methane collection chamber. In this chamber the gas reacts partially with water and converted into methanol and the process is accelerated by addition of extra water.

\subsection{Power from Methane Fuel Cell}

In the plant the methanol passes from the methane collection chamber to the fuel cell (MFC). The methanol gas is allowed to react with sufficient quantity of water and $\mathrm{H}+$ ions and electrons are produced as result it acts as anode. The $\mathrm{H}+$ ions pass through the electrolyte. These electrons travel through the external circuit and load and therefore electric power is generated. The overall cell reaction is:

\section{$\mathrm{CH} 3 \mathrm{OH}+3 / 2 \mathrm{O} 2 \rightarrow \mathrm{CO} 2+2 \mathrm{H} 2 \mathrm{O}+\Delta \mathrm{E}$}

$\Delta \mathrm{E}=$ Energy generated

\subsection{Electric Power Control Unit}

This unit receives electric power from both EPG and MFC. One part of the total power fed to EPCU is drawn by the heating unit and rest of the power is available for use.

\section{ECONOMIC ANALYSIS OF BIOGAS ELECTRIC GENERATION \\ 7.1 Case1 \\ Monthly wastage collection for drinking, bathing, cooking and cleaning of area of residence:}

Approximate dispose of solid + liquid wastage per person per day $=200$ litres

Estimated wastage of solid + liquid per day for four persons $=$ 800 litres

Monthly wastage collection for drinking, bathing and cleaning of area of cattle:

Approximate dispose of solid + liquid per cow and calf per day $=150$ litres

Estimated wastage of solid + liquid per day for four cows and calves $=600$ litres

\section{Total monthly dispose of into the septic tank}

Estimated monthly dispose of four persons $=24000$ litres

Estimated monthly dispose of four cows and calves $=18000$ litres

Total monthly dispose $=42000$ litres

One liter of waste corresponds to power 0.1402W [12].

42000 litres waste generated electric power $5.88 \mathrm{KW}$

Monthly electric power consumption by heating unit and feed pump $=3 \mathrm{KW}$

Available power for use $=5.88-3=2.88 \mathrm{KW}$

Connected load of the house $=5 \mathrm{KW}$

$\%$ age of electric power share of biogas plant $=57.6 \%$

$\%$ age of electric power share from market $=42.4 \%$ 


\subsection{Case2}

Monthly wastage collection for drinking, bathing, cooking and cleaning of area of residence:

Approximate dispose of solid + liquid wastage per person per day $=200$ litres

Estimated wastage of solid + liquid per day for six persons $=$ 1200 litres

Monthly wastage collection for drinking, bathing and cleaning of area of cattle:

Approximate dispose of solid + liquid per cow and calf per day $=150$ litres

Estimated wastage of solid + liquid per day for six cows and calves $=900$ litres

\section{Total monthly dispose of into the septic tank}

Estimated monthly dispose of six persons $=36000$ litres

Estimated monthly dispose of four cows and calves $=27000$ litres

Total monthly dispose $=63000$ litres

One liter of waste corresponds to power 0.1402W [12]

63000 litres waste generated electric power $8.83 \mathrm{KW}$

Monthly electric power consumption by heating unit and feed pump $=3 \mathrm{KW}$

Available power for use $=8.83-3=5.83 \mathrm{KW}$

Connected load of the house $=5 \mathrm{KW}$

The electricity from market is not required in this case as available power from biogas in enough for the load connected with the house.

\section{CONCLUSION}

The domestic waste electric power generation from biogas plant gives a new development savings of fossils and protection of environment. Considering case1, on an average $60 \%$ saving in power and electricity bill is a significant economic achievement of a developing country. The byproduct of the plant used as manure which is rich in nitrogen and conserves the fertility rate of the agriculture land. It is also seen that as much energy is produced from the waste, less electricity from market is required and in some cases it is possible that the load required is satisfied with the biogas energy only as in case2. The excess of gas produced can be used as a combustion fuel in automobiles and thereby reducing the pressure of procurement of crude oil.

\section{REFERNCES}

[1] M. Niino et al. "Research Project on the Effective Use of Untapped Thermal Energy from Garbage Incineration etc." International Conference on Thermoelectrics 1997, pp. 539-546.
[2] J. M. Pearce et al. "Electricity generation in the home: Modeling of single-house domestic combined heat and power" IEEE Proceedings-Science Mens. Technology, Vol. 148, No. 5, September 2001, pp. 197-203.

[3] K.M. Leung et al. "Renewable Energy Development in Hong Kong" IEEE International Conference oTechnologies (DRPT 2004), April 2004, Vol. 1, pp. 399-404.

[4] N. Barsoum et al. "Modeling and Cost Simulation of Stand-alone Solar and Biomass Energy" International Conference on Modelling\& Simulation 2008, pp. 1-6.

[5] Junichi Arai et al. "Power Electronics and its application to renewable energy in Japan" IEEE Circuits \& Systems magazine 2008, pp. 52-66

[6] Weizhu Shi et al. "Performance Simulation of Gas Turbine Combined Cycle with Coke Oven Gas as Fuel" Power and Energy Engineering Conference 2009, pp. 1-4

[7] V. Kallimani et al. "Design and development of a compact high rate digester for rapid bio methanation from a kitchen waste for Energy generation" International conference on Sustainable Energy Technologies (ICSET), pp. 1-4

[8] M.S.Murthy et al. "Revolving Doors Producing Green Energy" IEEE First Conference on Clean Energy and Technology CET 2011, pp. 157-160

[9] A. M. Hasan et al. "Community Based Bio Gas plants for Socio-Economic Development of Rural Bangladesh" International conference on Developments in Renewable Energy Technology (ICDRET'2012), pp. 1-4

[10] U. Anitha et al. "Renewable Energy Technology in India: Panacea for Sustainable Development" International Conference on Advances in Engineering, Science and Management (ICAESM -2012), pp. 137-141

[11] M. Faisal Matin et al. "Hybrid Power Generation to Meet the Increasing Demand of Energy for an Island of Bangladesh" Proceedings of 2013 2nd International Conference on Advances in Electrical Engineering (ICAEE 2013), pp. 368-373

[12] M. Raman et al. "Analysis and Design of Embedded Controller Based Electrical Power Generation Unit from Domestic Waste" International Conference on Environmental Engineering and Applications (ICEEA 2010), pp. 63-67.

[13] Riek, Isabell et al. "Renewable Energy Generation from Biomass- Biogas in India" Center for Applied International Finance and Development (CAIFD), 2012 ISSN 2191-4850, pp. 1-106 